\title{
Drivers and deterrents of music streaming services purchase intention
}

\section{Teresa Fernandes* and João Guerra}

\author{
Faculty of Economics, \\ University of Porto, \\ Rua Dr. Roberto Frias, s/n, 4200-464 Porto, Portugal \\ Email: tfernandes@fep.up.pt \\ Email: joaoguerra45@gmail.com \\ *Corresponding author
}

\begin{abstract}
Generalised access to online content, with no transfer of ownership, revolutionised consumer behaviour. The music industry is a paradigmatic example: physical product sales decreased and even online music stores are increasingly threatened by the rise of on-demand music streaming services (MSS). However, MSS find it difficult to persuade users to opt for the premium version. Therefore, the purpose of this study is to assess what drives (deters) users' intention to purchase MSS, as well as to examine the role of gender and age. Based on data collected from 318 MSS users, the study shows that both perceived value and perceived fee are significant predictors of MSS purchase intention, with the negative impact of the latter surpassing the positive one of the former, while the moderating effect of age and gender was supported. Our study contributes to a deeper understanding of MSS purchase intention, and offers important insights to MSS providers.
\end{abstract}

Keywords: online content; music streaming services; MSSs; freemium; purchase intention; technology acceptance model; TAM; value-based adoption model; VAM; gender; age.

Reference to this paper should be made as follows: Fernandes, T. and Guerra, J. (xxxx) 'Drivers and deterrents of music streaming services purchase intention', Int. J. Electronic Business, Vol. X, No. Y, pp.xxx-xxx.

Biographical notes: Teresa Fernandes obtained her BS, MBA, and PhD from the University of Porto. She is an Assistant Professor at the University of Porto, where she is also the Director of the MSc in Services Management and lectures in the area of services and digital marketing. Her research focuses on customer services, relationships, engagement and experience. Her research has been published in the Journal of Services Marketing, Journal of Retailing and Consumer Services, Journal of Marketing Management, Journal of Business and Industrial Marketing, Journal of Strategic Marketing, among others

João Guerra is a former Master's student from the Faculty of Economics, University of Porto, Portugal. He has professional experience in the areas of innovation, entrepreneurship and investment management gained from his work in a start-up accelerator and in a consulting firm. He holds a Master's in Management from the Faculty of Economics, University of Porto, Portugal.

This paper is a revised and expanded version of a paper entitled 'Purchase intention of online content: an application to music streaming services' presented at AMA SERVSIG, Maastricht University, The Netherlands, 17-19 June 2016. 


\section{Introduction}

With the rise of the internet and increased reliance on IT-based e-commerce systems, sharing goods and services through information technology was facilitated (Hamari et al., 2016), from peer-to-peer accommodation to car sharing ( $\mathrm{PwC}, 2015)$. In particular, online content service industries have grown rapidly (Wang et al., 2013): the web revolution brought the possibility to access online content that used to be available only offline, on-demand and with no transfer of ownership (Bardhi and Eckhardt, 2012; Lin et al., 2013). Online content refers to the category of digital content shared and distributed through online channels, such as online videos and games, electronic journals, e-books and, the focus of this study, digital music (Li and Cheng, 2014).

The music industry is a paradigmatic example of this revolution: before digitisation, record labels controlled their own value chain, from signing new artists to distributing their music to record stores (Nylén and Holmström, 2015). Only big bands with professional and influential support would be able to generate a significant amount of income in this environment. Nowadays, with the digitisation of music, the artists themselves make their own decisions concerning marketing and promotion of their records. The rise of digital channels brought significant changes into the music field and the industry structure has undergone a deep transformation process (Warr and Goode, 2011), with a strong growth of digital sales in recent years and the development of new business models (Wlömert and Papies, 2016). Hence, the music industry constitutes a challenging, highly dynamic, yet under researched, marketing environment (Hollebeek et al., 2016; Sinclair and Green, 2016).

The way consumers listen to music has also changed, mainly through access made easier in the internet through digital spaces and streaming platforms like iTunes or Spotify (Sinclair and Tinson, 2017). Nowadays, consumers face "a myriad of music platforms with widely different characteristics in terms of business model (advertising supported, fee-based, etc.) delivery mode (streaming, downloading, etc.) and others" [Weitjers et al., (2014), p.537]. Through new concepts of digital music distribution (Doerr et al., 2010) such as music as a service (MaaS), fans everywhere can now listen to every song of every band over the internet as a service, blurring national boundaries. Digital music came to stay, accounting for the first time for over 50\% (54\%) of total industry revenues (IFPI, 2018), while conversely physical product sales are declining (Sinclair and Tinson, 2017) together with illegal downloading (Sinclair and Green, 2016). In particular, licensed music streaming services (MSS) overcame $\$ 17.3$ billion of sales in 2017 , following a $41.1 \%$ sharp growth (IFPI, 2018), and are expected to reach a total of 978 million users and 220 million subscribers by 2020 (Statista, 2018b). As such, it became the fastest growing music option, offering millions of songs from different record labels (Cesareo and Pastore, 2014) which are streamed instead of being downloaded, without transferring ownership (Doerr et al., 2013). In fact, the underlying concept of MSS relies on inducing consumers to listen to streamed music on demand. The majority of these MSS providers use the 'freemium' model (Anderson, 2009), where the core, basic version is offered for free, while revenues are generated through the sales of paid premium versions (Hamari et al., 2017a; Sinclair and Tinson, 2017). Freemium, an increasingly dominant business model for today's services, is a promising solution to earn money, now that the 'digitally embracing' and 'device connected' Web 2.0 users feel increasingly entitled to free services (Dou, 2004; Wang et al., 2005; Pauwels and Weiss, 2008; Veit et al., 2014). This business model draws a large customer base with 
free entry pricing (Hamari et al., 2017a; Chen et al., 2018a), which can then be monetised through an upgraded version available for a subscription fee (Mantymaki and Salo, 2015; Vock et al., 2013). By giving access to a free version, providers hope to optimise consumer trial and, over time, engagement with the service, which could lead users to opt for the premium version (Dinsmore et al., 2017). Users can listen to almost every song available by using the free version of the service, but paying customers have several advantages, like no advertising, better sound quality, unrestricted access to the catalogue, offline listening and the option to download their favourite albums (Sinclair and Tinson, 2017; Wagner et al., 2014). These paying premium users not only allow financing non-paying users, which cause almost no marginal costs, but also help providers to pay royalties to the music license holder: therefore, it is critical for the long-term viability of MSS to improve their conversion rates (Wagner et al., 2014; Wang et al.,. 2005). However, MSS face the challenge of persuading users to opt for the for-fee version (Doerr et al., 2010; Dinsmore et al., 2017), since consumers who are accustomed to free content seem unready to embrace this practice (Dou, 2004; Li and Cheng, 2014; Lin et al., 2013; Yang et al., 2015). Moreover, the peculiarities of online content as a paid product (namely, the existence of many undifferentiated free alternatives) also constitutes a challenge for these services (Dou, 2004; Pauwels and Weiss, 2008; Vock et al., 2013). According to the IFPI (2016), nearly a billion listeners use free ad-supported versions, which compares to paid subscribers, who currently number around 100 million. According to Statista (2017), MSS will reach 1,350 million users worldwide by 2020, but less than $15 \%$ will be paid subscribers. As of June 2018, Spotify had 200 million active users, of which only 80 million are premium, while only 5.2 million from the 76.3 million users of Pandora are paying subscribers (Statista, 2018a). Therefore, in order to convert users to paid subscribers, understanding the reasons why they may choose to accept (or not) the premium option becomes crucial for MSS providers (Chen et al., 2018a).

But despite its relevance, very few studies have investigated the changing dynamics of music consumption (Sinclair and Green, 2016) or addressed freemium as a new type of revenue model in this industry (Wagner et al., 2014). Even fewer (e.g., Doerr et al., 2010; Oestreicher-Singer and Zalmanson, 2013) discuss consumers' acceptance of freemium as a model for accessing services and their willingness to pay for them, when free basic service is available (Doerr et al. 2013; Chen et al., 2018b). Therefore, our purpose is to assess what drives (or deters) users' intention to purchase MSS, by examining the relationship between consumers' perceptions and demographic characteristics, and their willingness to pay for MSS. Based on the technology acceptance model (TAM) and the value-based adoption model (VAM), a research model was tested, using data collected from 318 freemium MSS users.

The remainder of this study is structured as follows. First, we present the literature review relevant to this study and develop the research hypotheses. Then, we describe the methodology used, and we present and discuss the research findings. We conclude by presenting final conclusions, contributions and suggestions for future research. 


\section{Conceptual background}

Offering services for free to at least a segment of the customer base became a prevalent business model online, with consumers being able to choose from a multitude of free e-services (Anderl et al., 2016), especially within hedonic-oriented and entertainment online content (Chu and $\mathrm{Lu}, 2007$ ). In the music industry, these online business models include streaming services (Sinclair and Tinson, 2017), which rely on either subscription fees (paid streaming services) and/or advertising (providing streaming free of charge) as sources of revenue (e.g., Spotify). This so-called 'freemium' model (Anderson, 2009) is a topic of ongoing controversial debate in the music industry (Wlömert and Papies, 2016): while some industry representatives consider it a part of the 'music industry's digital revolution' (IFPI, 2016) and a way to expand the whole market, others question its sustainability and consider MSS harmful for the industry. This business model followed by MSS deviates from the traditional business model in the music industry and is designed to provide on-demand access to a comprehensive library of tracks rather than purchase individual music products (e.g., CDs or downloads) or even download-to-own (Doerr et al., 2013; Papies et al., 2011). The central point of MSS is not the sale or lending of music, but the service of making music available all the time (Doerr et al., 2010), allowing access over ownership (Bardhi and Eckhardt, 2012; Hamari et al., 2016; Sinclair and Tinson, 2017). The success of this model largely depends on consumer willingness to pay for freemium services (Li and Cheng, 2014; Wagner et al., 2014; Hamari et al., 2017a). Yet, persuading users to spend money on these services represents a major business challenge (Dinsmore et al., 2017), especially when consumers have plenty of free alternatives, a deeply entrenched 'free-lunch' mentality (Dou, 2004; Lin et al., 2013; Ye et al., 2004) and reference prices close to zero (Papies et al., 2011), which leads to a general belief that 'content is free' (Li and Cheng, 2014; Pauwels and Weiss, 2008; Yang et al., 2015). Furthermore, users may perceive a certain degree of unfairness associated with paying for online content, given that MSS advertising revenues are considered enough to support their financial viability (Lin et al., 2013; Ye et al., 2004; Wang et al., 2005). Hence, understanding the factors affecting consumer intention to subscribe or not to subscribe to the fee-based tier has become an important issue both for academics and practitioners (Pauwels and Weiss, 2008; Wang et al., 2005, 2013; Vock et al., 2013; Chen et al., 2018b).

However, there is a dearth of empirical research devoted to this important issue, and scant studies have investigated the willingness to pay for freemium access-based services. Doerr et al. (2010) explored the importance and the willingness to pay for attributes of MSS premium offers surveying a sample of 132 MSS users. Results show that contract duration, music quality and the possibility of offline access significantly increase users' willingness to pay by adding customer value to the service. Oestreicher-Singer and Zalmanson (2013) found out that very active network users are more willing to pay for freemium services. Vock et al. (2013) studied the willingness to pay for a social networking site (SNS) transitioning to a freemium-based model and found that the belief that the network represented a large, cohesive community, as well as perceived social capital from the site, had a positive association with users' willingness to pay for premium services. Wagner et al. (2014) analysed whether a free service's limitations impact the evaluation of free and premium versions, and concluded that companies providing freemium services can increase conversion by providing a strong functional fit benefit between their free and premium services. Hamari et al. (2017b) empirically 
studied how perceived service quality predicts customers' willingness to continue using freemium services and to purchase premium content in the context of free-to-play games, and concluded that that perceived quality of the freemium service had little effect on purchases of premium content, except through the increased willingness to use the freemium service. According to the authors, users are probably already fairly satisfied with the free core service, and therefore higher service quality has a negligible effect on their purchase decisions. Chen et al. (2018a) empirically tested social and psychological constructs and their impact on MSS purchase intentions and concluded that social influence impacts attitudes towards MSS, which in turn drive purchase intention, while continuance intention of paid music streaming is driven by hedonic performance expectancy of consumers. Beyond access-based services, other studies focused on the willingness to pay for online content (Table 1), mainly based on the TAM and the VAM. These studies highlight the role of customers' perceived value (PV) ( $\mathrm{Li}$ and Cheng, 2014), and regard it as the most critical factor to be considered (Chu and $\mathrm{Lu}, 2007$; $\mathrm{Lu}$ and Hsiao, 2010). PV is conceptualised as involving a consumer's assessment of the ratio of perceived benefits to perceived costs (Wang et al. 2013). It involves a trade-off of 'give' (i.e., perceived sacrifices) and 'get' (i.e., perceived benefits) components (Li and Cheng, 2014).

The TAM, developed by Davis (1989), is regarded as one of the most important models in the area of user acceptance of technology (Borges et al., 2015; Chen et al., 2016). In TAM, user acceptance is analysed through two important measures, usefulness and ease of use. According to Davis (1989), the first is "the degree to which an individual believes that using a particular system would enhance his/her job performance," while the second refers to "the degree to which an individual believes that using a particular system would be free of physical and mental efforts." Various studies based on TAM (e.g., Cheong and Park, 2005; Wu et al., 2016; Zhang et al., 2018) showed that this model is a good predictor of users' actual technology usage. Nevertheless, there are situations in which TAM was not so accurate. In the context of online content services, many users may be reluctant to use for-fee information services even if it is useful for them (Wang, 2008). TAM's perceived usefulness (PU) only taps the perceived benefit component, omitting the perceived cost. To solve this issue, many models were addressed, including the revised TAM (Wang, 2008) which replaces PU with PV. Moreover, Venkatesh and Bala (2008) proposed an upgrade of the original TAM, the TAM 3. In this model, the determinants of PU and ease of use are separated, meaning that the processes of the first do not explain the processes of the second and vice versa. For example, high levels of computer playfulness do not necessarily enhance usefulness. These modifications expand the original model, but preserve it as a goal-oriented technology adoption model, related to its technical performance and usability (Morgan-Thomas and Veloutsou, 2013).

An alternative model is the VAM proposed by Kim et al. (2007). This value-based approach explains customers' usage intention from the value-maximisation perspective, and it was developed to overtake the weaknesses of TAM in explaining new technology adoption, such as mobile technologies (Borges et al., 2015). Given that satisfaction itself is no longer enough to explain technology adoption, in VAM PV is a main determinant of user adoption and is determined by two cost beliefs (perceived fee - PF and technicality) and two benefit beliefs (usefulness and enjoyment). While PU refers to functional value, perceived enjoyment (PE) refers to hedonic value, and plays also an important role in determining usage behaviours (Chen et al., 2016, 2018a). Authors such as Wang et al. 
(2013, 2018) or Chu and $\mathrm{Lu}(2007)$ also support the notion that utilitarian and hedonic benefits have a great influence on PV (Table 1). Wang et al. (2013) studied purchase intention of online music services, confronting two benefit beliefs (usefulness and enjoyment) and two cost beliefs ( $\mathrm{PF}$ and technicality), and demonstrated the positive influence of PV on purchase intention. Chu and $\mathrm{Lu}$ (2007) extended TAM by incorporating the value-intention framework to investigate the purchase behaviour of early adopters of online music. The authors found two beneficial factors (usefulness and playfulness) had a positive influence on purchase intention, while perceived price was the most direct monetary sacrifice, negatively relating to PV. Regarding mobile navigation apps, Wang et al. (2018) found that benefits such as enjoyment positively influenced purchase intention, while complexity had a negative effect. Thus, VAM captures both sacrifice and benefit dimensions, which people usually consider before decision-making (Zheng et al., 2015) and can be used to explain and predict purchase intention of online content (Wang et al., 2013, 2018), such as MSS, the focus of this study.

Table 1 Overview of the relevant literature on willingness to pay for online content using TAM and VAM

\begin{tabular}{|c|c|c|c|}
\hline Study & Theory/model & Research goal & Main findings \\
\hline $\begin{array}{l}\text { Cheong } \\
\text { and } \\
\text { Park } \\
(2005)\end{array}$ & TAM & $\begin{array}{l}\text { Examine the motivations } \\
\text { and the behavioural aspects } \\
\text { behind the mobile internet } \\
\text { acceptance in Korea }\end{array}$ & $\begin{array}{l}\text { Usefulness, playfulness, perceived } \\
\text { price and attitudes towards } \\
\text { technology have influence on the } \\
\text { behavioural intention to use it }\end{array}$ \\
\hline $\begin{array}{l}\text { Kim } \\
\text { et al. } \\
(2007)\end{array}$ & VAM & $\begin{array}{l}\text { Adoption of mobile internet } \\
\text { in Singapore }\end{array}$ & $\begin{array}{l}\text { Sacrifice components (technicality } \\
\text { and perceived fee) contribute more } \\
\text { to perceived value than benefits } \\
\text { (usefulness and enjoyment) }\end{array}$ \\
\hline $\begin{array}{l}\text { Chu } \\
\text { and } \mathrm{Lu} \\
(2007)\end{array}$ & TAM, VAM & $\begin{array}{l}\text { Examine the purchase } \\
\text { behaviour of online music } \\
\text { early adopters in Taiwan }\end{array}$ & $\begin{array}{l}\text { Two benefits (usefulness and } \\
\text { playfulness) have a positive } \\
\text { influence on purchase intention. } \\
\text { Perceived sacrifice (price) } \\
\text { negatively relates to perceived value }\end{array}$ \\
\hline $\begin{array}{l}\text { Wang } \\
\text { et al. } \\
(2013)\end{array}$ & VAM & $\begin{array}{l}\text { Understand the factors } \\
\text { affecting purchase intention } \\
\text { of online music services in } \\
\text { Taiwan }\end{array}$ & $\begin{array}{l}\text { Antecedents (except technicality) } \\
\text { influence purchase intention } \\
\text { (through perceived value) }\end{array}$ \\
\hline $\begin{array}{l}\text { Wang } \\
\text { et al. } \\
(2018)\end{array}$ & VAM & $\begin{array}{l}\text { Examine the purchase } \\
\text { intention of mobile GPS } \\
\text { navigation apps in Taiwan }\end{array}$ & $\begin{array}{l}\text { Compatibility, relative advantage, } \\
\text { perceived enjoyment, cost } \\
\text { (positively) and complexity } \\
\text { (negatively) influence perceived } \\
\text { value and purchase intention }\end{array}$ \\
\hline
\end{tabular}

\section{Research framework and methodology}

The purpose of this study is to assess what drives (or deters) users' intention to purchase MSS and pay the for-fee version of the service, considering the role of age and gender. Based on existing models in the literature, namely TAM and VAM, a research model was developed, including variables such as PU, PE, PV, PF, technicality, age and gender to build the research hypotheses (Figure 1). 
Figure 1 Research framework (see online version for colours)

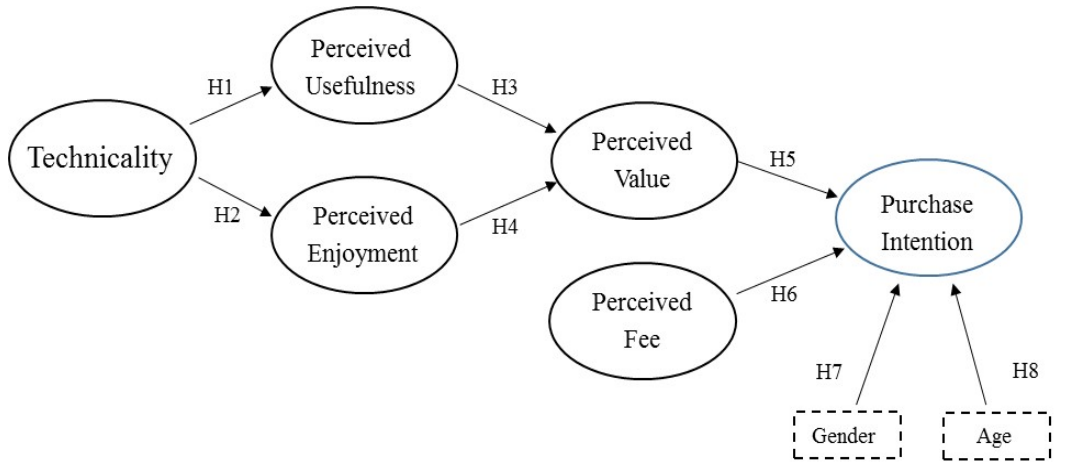

Technicality was regarded in this study as an antecedent of PU and enjoyment. According to Wang et al. (2013), technicality can be defined as "the extent to which a customer believes that using an online content service would suffer from physical, mental and learning effort" (p.203). Considering technicality as a non-monetary cost (Kim et al., 2007), a negative impact on both constructs is expected. In his research about user acceptance of information technology, Davis (1993) found a strong relationship between technicality and PU, as well as Cheong and Park (2005) and Teo et al. (1999). Further, the influence of technicality on enjoyment was demonstrated by Moon and Kim (2001), who found that perceived ease of use has a strong impact in PE. As such, we consider that:

H1 Technicality is negatively related to PU in the context of MSS.

H2 Technicality is negatively related to PE in the context of MSS.

Considering the relationship between usefulness, enjoyment, and PV, Wang et al. (2013) suggested that the so-called utilitarian (usefulness) and hedonic (enjoyment) benefits have a great influence on PV, despite considering the influence of the latter higher. The same was found by $\mathrm{Chu}$ and $\mathrm{Lu}$ (2007) in a research that assessed the factors that drive music purchase intention in Taiwan. Kim et al. (2007) also supports the idea that both PU and enjoyment affect PV; however, unlike the previous examples, in their study the difference between both impacts is blurred. A different approach was followed by Van der Heijden (2004), who associates directly PU and PE to adoption intention (without PV as mediator) in a study about user acceptance on hedonic systems. According to Hampton-Sosa (2017), MSS that are useful and provide enjoyment lead to adoption. As such, we posit that:

H3 PU is positively related to PV in the context of MSS.

$\mathrm{H} 4 \mathrm{PE}$ is positively related to PV in the context of MSS.

This research further considered PV and PF as antecedents of purchase intention of MSS. Previous studies on online contexts (e.g., Chu and Lu, 2007; Kim et al., 2007; Lu and Hsiao, 2010; Lin et al., 2013; Wang et al., 2013; Vock et al., 2013; Hsiao and Chen, 2016) found that PV has a positive impact on purchase intention. For instance, Lu and Hsiao (2010) and Vock et al. (2013) assessed the intention to pay for social network sites, 
Wang et al. (2013) studied the purchase intention of online content services, and Hsiao and Chen (2016) examined in-app purchase intention for mobile games. Regarding PF, a direct monetary sacrifice, a negative impact on consumers' willingness to pay is expected (Lin et al., 2013). Andersson and Heinonen (2002), in a study about the acceptance of mobile services, suggested that the fact of having a fee involved when trying a new service can prevent users from really using it. Cheong and Park (2005) also alerted to the negative influence of perceived price on the intention to use mobile internet, as well as, Liao and Cheung (2001) in their research on internet-based e-shopping. We thus suggest that:

H5 PV is positively related to purchase intention in the context of MSS.

H6 PF is negatively related to purchase intention in the context of MSS.

Different demographic characteristics (gender, age) may also lead consumers to hold different attitudes regarding paying for MSS. In fact, several studies suggest that males and females differ in their decision-making processes, and have different gender-based perceptions regarding technology (Venkatesh and Morris, 2000), which can influence their preferences regarding, e.g., online shopping (Cyr and Bonanni, 2005) or mobile apps (Leon, 2018). However, gender role has been scarcely investigated regarding online purchase intentions (Chiu et al., 2005; Slyke et al., 2002), and even less when purchases refer to online content. Not only relatively little research has been done in this area, but also results have been mixed. Historically, and regarding e-commerce of goods, research has found that men are more likely to make online purchases and that they tend to focus more on the value gained through the purchase, while women focus more on trustworthiness, assurance and social factors (Cyr and Bonanni, 2005; Hwang, 2010; Venkatesh and Morris, 2000). However, in their study on online purchase intentions in e-tail services, Chiu et al. (2005) concluded that men are less likely to consider the internet useful for making purchases than women. Furthermore, online purchasing is an innovative way to acquire goods and services, and hence the level of innovativeness among females could be expected to lead to higher online purchase intentions when compared with men (Chiu et al., 2005). Nevertheless, since females take more time to get used and familiarise themselves with internet applications than men (Teo and Lim, 1996) and have potentially higher levels of computer anxiety (Venkatesh and Morris, 2000), this may reflect that females have great difficulty than males in performing online purchases (Brown et al., 2003; Chiu et al., 2005). Considering online content purchases, Hamari et al. (2017b) found females to be less likely to purchase premium content in the context of free-to-play games. Regarding willingness to pay for online news, gender was found to influence paying intent, which for Chyi and Lee (2013) is higher for men, while Punj (2015) concluded the opposite. Finally, Ye et al. (2004) found no gender differences regarding online content purchases, and $\mathrm{Lu}$ and Hsiao (2010), while studying the influence of extro/introversion on the intention to pay for SNS, found that gender (along with age and income) had no effect on payment intention. Given the lack of consistency in the literature regarding the relationship between gender and online purchases, and the relative absence of studies considering its role in the context of purchase intention of freemium services, we hypothesise that:

H7 Purchase intention varies significantly according to gender in the context of MSS. 
Also age is a widely used demographic variable to characterise the adoption of technologies (Morris and Venkatesh, 2000). Usually, older people feel less comfortable when dealing with new technologies, while youngsters tend to be early adopters (Kumar and Lim, 2008; Lee and Yang, 2013; Pagani, 2004). Younger users show greater predisposition and trust towards new technologies, find them easier to use, and thus dedicate less effort to examining its details and evaluating its quality (Liébana-Cabanillas et al., 2014, 2018). However, the role of age in predicting online purchase intentions remains an open question (Sorce et al., 2005). Regarding purchases of goods, previous studies concluded that younger people are more likely to shop online (Stafford et al., 2004) and to purchase virtual reality hardware (Manis and Choi, 2018). Yet, other studies determined that older users were more likely to buy online (Donthu and Garcia, 1999) or to purchase smart homes (Shin et al., 2018), and Sorce et al. (2005) found that older consumers purchased as much as youngsters online. In general, older users are also reported to be inherently more price-conscious and known to expect value for money in a purchase when compared to the younger generations (Kumar and Lim, 2008), while young people value the convenience, information availability and good deals of online shopping (Yang et al., 2015). Considering online content, Ye et al. (2004) suggest that older consumers may be more willing to use fee-based online services than younger ones, while Chyi and Lee (2013) and Punj (2015) concluded that younger people are more likely to pay for online news, since older people are more used to consume traditional media content. Also Yang et al. (2015) empirically demonstrated that age is negatively related to willingness to pay for online content (particularly entertainment content), mainly due to new media dependency, even though disposable income is lower for young people. In the context of online music, Weitjers et al. (2014) found that youngsters are more open to advertising and to the versatility of streaming, while middle-aged adults are more willing to pay for advertising-free platforms and are more likely to prefer ownership over access. Given the lack of consistency regarding the impact of age on online purchases, and the relative absence of studies considering its role in the context of MSS purchase intention, we hypothesise that:

H8 Purchase intention varies significantly according to age in the context of MSS.

Data was collected through a web-based cross-sectional survey based on a convenience sample of freemium streaming users, using the free-tier of a self-selected MSS (e.g., Spotify, Deezer, Pandora, etc). Measures were established scales from previous studies (Chu and Lu, 2007; Wang et al., 2013). Three hundred eighteen valid responses were gathered. The majority of the respondents $(61 \%)$ was female, aged between 15-24 years old $(76 \%)$.

Partial least squares structural equation modelling (PLS-SEM) using the SmartPLS 3.0 software (Henseler et al., 2009) was used to perform the data analysis, as the study's primary focus is on the model's overall predictive capacity or influence on the endogenous variables (Reinartz et al., 2009), and this modelling technique is well-suited for assessing complex predictive models (Hair et al., 2012). Furthermore, PLS does not require data normality (Henseler et al., 2009), and it is less demanding with respect to sample size (Hair et al., 2011; Zheng et al., 2015). In order to reduce potential common method variance, we used existing scales and ensured the respondents' anonymity (Podsakoff et al., 2012). In addition, we examined common method bias by performing the Harman's single-factor test (Harman, 1976; Podsakoff et al., 2003), which 
demonstrated that none of the factors accounted for the majority of covariance among items. Finally, the correlation matrix (Table 3) does not indicate any highly correlated factors, whereas according to Pavlou et al. (2007) evidence of common method bias should have resulted in extremely high correlations $(r>90)$. Therefore, we consider common method bias not to be a serious threat to our analyses. The advocated two-step procedure of evaluating the measurement (outer) model first, followed by an estimation of the structural (inner) model was followed (Diamantopoulos and Winklhofer, 2001).

\section{Validation of the measurement model}

Composite measures of identified factors were unidimensional and demonstrated good scale reliability according to accepted standards (Nunnaly, 1978). Identified factors showed strong Cronbach's alpha (ranging from .59 to .97). Composite reliabilities (CR) and average variances extracted (AVE) were above recommended minimums of .70 and .50, respectively (Fornell and Lacker, 1981; Hair et al., 2010), except for 'technicality'. However, since AVE was close to .50 , it was deemed acceptable to keep the factor (Table 2).

Table 2 Measurement scales, reliability and dimensionality statistic

\begin{tabular}{|c|c|c|c|c|}
\hline Measures & Loadings & t-value & Means & $C R(A V E)$ \\
\hline Technicality $(\alpha=.593)$ & & & 2.498 & $.766(.451)$ \\
\hline $\begin{array}{l}\text { It is not easy to use the music streaming } \\
\text { service }\end{array}$ & .702 & 8.218 & 2.031 & \\
\hline $\begin{array}{l}\text { Learning to use the streaming service is a } \\
\text { process requiring effort }\end{array}$ & .635 & 4.829 & 2.456 & \\
\hline $\begin{array}{l}\text { The music streaming service can be } \\
\text { accessed instantly (reversed) }\end{array}$ & .637 & 25.490 & 2.283 & \\
\hline $\begin{array}{l}\text { It is not easy to get the streaming service to } \\
\text { do what I want to do }\end{array}$ & .709 & 7.793 & 3.223 & \\
\hline Perceived usefulness ( $\alpha=.843$ ) & & & 6.015 & $.888(.615)$ \\
\hline $\begin{array}{l}\text { Using the music streaming service helps me } \\
\text { to access music content more quickly }\end{array}$ & .757 & 20.788 & 6.217 & \\
\hline $\begin{array}{l}\text { Using the music streaming service enables } \\
\text { me to enhance my music appreciation }\end{array}$ & .740 & 28.830 & 5.465 & \\
\hline $\begin{array}{l}\text { Using the music streaming service makes it } \\
\text { easier to get the music information }\end{array}$ & .740 & 20.143 & 5.774 & \\
\hline $\begin{array}{l}\text { The music streaming service provides a } \\
\text { wide variety of music }\end{array}$ & .830 & 29.709 & 6.314 & \\
\hline $\begin{array}{l}\text { Overall the streaming service is very useful } \\
\text { to listen to music }\end{array}$ & .837 & 36.689 & 6.305 & \\
\hline Perceived enjoyment ( $\alpha=.824)$ & & & 5.713 & $.884(.656)$ \\
\hline $\begin{array}{l}\text { I have fun interacting with the music } \\
\text { streaming service }\end{array}$ & .807 & 27.369 & 5.456 & \\
\hline $\begin{array}{l}\text { Using the music streaming service provides } \\
\text { a lot of enjoyment }\end{array}$ & .836 & 38.695 & 5.585 & \\
\hline
\end{tabular}


Table 2 Measurement scales, reliability and dimensionality statistic (continued)

\begin{tabular}{|c|c|c|c|c|}
\hline Measures & Loadings & t-value & Means & $C R(A V E)$ \\
\hline Perceived enjoyment $(\alpha=.824)$ & & & 5.713 & $.884(.656)$ \\
\hline I enjoy using the music streaming service & .861 & 52.517 & 6.097 & \\
\hline $\begin{array}{l}\text { Overall, using the music streaming service is } \\
\text { interesting to me }\end{array}$ & .730 & 21.324 & 4.960 & \\
\hline Perceived value $(\alpha=.809)$ & & & 5.709 & $.888(.727)$ \\
\hline $\begin{array}{l}\text { Compared to the effort I need to put in, the } \\
\text { use of the music streaming service is } \\
\text { worthwhile for me }\end{array}$ & .871 & 34.556 & 5.726 & \\
\hline $\begin{array}{l}\text { Compared to the time I need to spend } \\
\text { accessing, the use of the music streaming } \\
\text { service is worthwhile for me }\end{array}$ & .914 & 86.249 & 5.739 & \\
\hline $\begin{array}{l}\text { Overall, the music streaming service } \\
\text { delivers me good value }\end{array}$ & .766 & 23.239 & 5.660 & \\
\hline Perceived fee $(\alpha=.671)$ & & & 4.513 & $811(.591)$ \\
\hline $\begin{array}{l}\text { The price to pay to access the paid tier of the } \\
\text { music streaming service is too high }\end{array}$ & .665 & 10.367 & 4.613 & \\
\hline $\begin{array}{l}\text { The price to pay to access the paid tier of the } \\
\text { music streaming service is not reasonable }\end{array}$ & .795 & 20.036 & 3.956 & \\
\hline $\begin{array}{l}\text { Pay to access the paid tier of the music } \\
\text { streaming service is something that would } \\
\text { not please me }\end{array}$ & .836 & 31.545 & 4.969 & \\
\hline Purchase intention $(\alpha=.969)$ & & & 3.037 & $.980(.941)$ \\
\hline $\begin{array}{l}\text { I would consider to use the paid tier of the } \\
\text { music streaming service }\end{array}$ & .960 & 132.117 & 3.267 & \\
\hline $\begin{array}{l}\text { I would be willing to pay to access the paid } \\
\text { tier of the music streaming service }\end{array}$ & .986 & 473.135 & 2.984 & \\
\hline $\begin{array}{l}\text { In a near future, I would consider purchase } \\
\text { the access to the music streaming service }\end{array}$ & .964 & 171.518 & 2.858 & \\
\hline
\end{tabular}

Convergent and discriminant validity were demonstrated by factor loadings and by investigating the latent constructs correlations and the square root of their specific AVE, respectively. All factor loadings for indicators measuring the same construct were statistically significant $(\mathrm{p}<.01)$, supporting convergent validity. Moreover, estimated pair-wise correlations between factors:

1 did not exceed 0.85 and were significantly less than one (Bagozzi and Yi, 1988)

2 the square root of AVE for each construct was higher than the correlations between them (Fornell and Lacker, 1981), thus supporting discriminant validity (Anderson and Gerbing, 1988).

The only exception was the correlation between 'PU' and 'PE'. However, and provided the fact that both presented similar figures (.784 to .809), no changes were made. Table 3 shows the means, reliabilities and correlations between the constructs. 
Table 3 Means, reliabilities and correlations between each construct

\begin{tabular}{lcccccccccc}
\hline Construct & Mean & $A$ & $C R$ & $A V E$ & $T E$ & $P U$ & $P E$ & $P V$ & $P F$ & $P I$ \\
\hline TE & 2.498 & .593 & .732 & .418 & .647 & & & & & \\
PU & 6.051 & .843 & .888 & .615 & -.607 & .784 & & & & \\
PE & 5.525 & .824 & .884 & .656 & -.572 & .810 & .813 & & & \\
PV & 5.709 & .809 & .888 & .727 & -.461 & .687 & .647 & .852 & & \\
PF & 4.513 & .671 & .811 & .591 & .061 & .107 & .008 & .058 & .760 & \\
PI & 3.037 & .969 & .980 & .941 & .006 & -.013 & .068 & .165 & -.497 & .970 \\
\hline
\end{tabular}

Notes: Diagonals are the square root of AVE of each factor; the remaining figures represent the correlations.

\section{Results of the structural equation model}

The analysis of the data kept on with the hypotheses testing. The structural model was estimated through a bootstrap re-sampling tool in order to determine path significances. The results (Table 4) indicate that all paths are statistically significant, with the structural model explaining $36.8 \%$ of the variance in PU, $32.7 \%$ of PE, $49.6 \%$ of PV and $28.5 \%$ of purchase intention.

Results provide support for $\mathrm{H} 1$ to $\mathrm{H} 6$, with a significant negative effect of technicality on both PU $(\beta=-.607, \mathrm{t}$-value $=16.68)$ and enjoyment $(\beta=-.572$, $\mathrm{t}$-value $=12.575)$, which in turn positively affect PV $(\beta=.475$, t-value $=5.919$; and $\beta=.261$, t-value $=3.468$, respectively); finally, $\mathrm{PV}$, together with $\mathrm{PF}$ had a significant effect on purchase intention $(\beta=.195$, $\mathrm{t}$-value $=4.162$; and $\beta=-.509$, $\mathrm{t}$-value $=11.226$, respectively).

Table 4 H1-H6 testing results according to the structural model

\begin{tabular}{lccccc}
\hline Dependent variable & Independent variable & Path coefficient & t-value & Sig. & R square \\
\hline Perceived usefulness & Technicality & -0.607 & 16.680 & 0.000 & 0.368 \\
Perceived enjoyment & Technicality & -0.572 & 12.575 & 0.000 & 0.327 \\
Perceived value & Perceived usefulness & 0.475 & 5.919 & 0.000 & 0.496 \\
& Perceived enjoyment & 0.261 & 3.468 & 0.001 & \\
Purchase intention & Perceived value & 0.195 & 4.162 & 0.000 & 0.285 \\
& Perceived fee & -0.509 & 11.266 & 0.000 & \\
\hline
\end{tabular}

To test the remaining hypotheses, we have analysed differences in purchase intention of MSS according to users' gender and age. Results shows that differences are statistically significant for gender $(\mathrm{MD}=.328 ; \mathrm{t}$-value $=2.877 ; \mathrm{p}<.01)$ and age $(\mathrm{MD}=-.486$; $\mathrm{t}$-value $=-3.757 ; \mathrm{p}<.00$ ). Pairwise comparisons revealed that purchase intention of MSS is lower for women and for youngsters, aged between 15-25 years old - the so-called 'digital natives' (Prensky, 2001) who grew up with digital media, are often early adopters of new technologies and extensive users of the internet (Kumar and Lim, 2008) - when compared with men and older users, with more than 26 years old, including not only young adults but also 'digital immigrants' (Prensky, 2001), who though increasingly dependent and more open to new media, learned digital skills mostly during adulthood (Yang et al., 2015). 


\section{Discussion}

Recently, new concepts of digital music distribution have been developed. A new type of business model, such as MSS, now provides content over the internet as a service, without transferring ownership. Most MSS adopt the freemium model, where services can be used both for free or with a paid subscription. However, questions arise about what factors govern the adoption of MSS and the willingness to pay for them. As such, the aim of this study was to fill a research gap by analysing users' purchase intention towards MSS. Based on the TAM and the VAM, a research model was developed, including drivers such as PU, PE, PV, PF and technicality. The role of age and gender was also addressed.

As expected, findings show that technicality, or the extent to which a user perceives the technical complexity of the service, negatively influences PU and PE, which is consistent with previous findings (e.g., Davis, 1993; Cheong and Park, 2005; Kim et al., 2007). Although users are increasingly more aware on how to deal with innovative systems, results suggest that the non-monetary costs brought by the physical and mental effort to learn can affect their sense of utility and joy. Regarding the impact of PU and PE on PV, the study concludes that usefulness (and not enjoyment) is the main source of value to MSS users, which is at odds with previous findings from, e.g., Wang et al. (2013) and Chu and $\mathrm{Lu}$ (2007) regarding online music consumption as a 'leisure-oriented activity' [Wang et al., (2013), p.205]. Results also seem to confirm the conclusions of Wagner et al. (2014), who concluded that users attitudes towards freemium MSS are mainly driven by cognition, as well as Chen et al. (2018a) results regarding the non-significant effect of hedonic performance on attitude towards paid streaming services, with the 'fun factor' only improving the likelihood that free users will continue to use the free MSS. According to Kim et al. (2007) and Chu and Lu (2007), PU is an extrinsic, functional and cognitive factor, while $\mathrm{PE}$ is an intrinsic, recreational and affective factor, independent from performance. Similarly, in their study on the intention to use mobile services, Nysveen et al. (2005) identify utilitarian and non-utilitarian motivations, with the first associated with core services and including factors such as PU and quality; and the second associated with value-added services and including factors such as enjoyment and entertainment. While functional users value core services the most, emotionally-involved consumers find value-added services more important (Kumar and Lim, 2008). Given that PV is mainly driven by PU when compared with PE, the study suggests that consumers (or at least those adopting the free-tier of the service) use MSS mainly for utilitarian purposes, and may thus be less interested to pay for the value-added, premium version.

Not surprisingly, results support that both PV (Chu and Lu, 2007, Kim et al., 2007, Wang et al., 2013, Vock et al., 2013) and PF (Liao and Cheung, 2001, Andersson and Heinonen, 2002, Cheong and Park, 2005, Lin et al., 2013) are significant predictors of MSS purchase intention, with the negative impact of the latter surpassing the positive one of the former. This suggests that, despite finding the service valuable, the fee involved is the main aspect that influences users' purchase decision. Nowadays, there are several alternatives to online content services, and, provided that the costs of change are low and the customers are willing to change, a possible fee involved can prevent many users of actually subscribing the service. In fact, purchase intention of respondents included in the sample - noticeably formed by freemium MSS users, adopting the free-tier of the 
service - was in average rather low (3.037 in a scale of 1 to 7 ), suggesting that the subscription-based model may be unattractive to many consumers, as acknowledged by Papies et al. (2011).

Finally, the study also concludes that demographic characteristics (namely gender and age) directly influence users' willingness to pay for MSS. Regarding gender, results suggest that men display a higher purchase intent of MSS, which confirms previous conclusions referring to other types of online content services, namely free-to-play games (Hamari et al., 2017b), online news (Chyi and Lee, 2013), and online purchasing in general (e.g., Brown et al., 2003; Chiu et al., 2005). Due to their practical sense, men rate functionality (a feature very much present in MSS) higher than women (Chiu et al., 2005), who instead value social factors, trust and subjective norms more (Venkatesh and Morris, 2010). Following the same line of thought, Punj (2015) concluded that women would be more likely to pay for online content if it emphasises the social aspect of information and are thus more likely to value virtual communities. Regarding this matter, Vock et al. (2013) found a positive association between the social capital of SNS and users' willingness to pay for premium services. Social capital is associated with the relationships between and within groups and is often defined in terms of social trust and norms (Vock et al., 2013).

In terms of age, results suggest that young users, namely 'digital natives', between 15 and 25 years old, exhibit a lower purchase intention of MSS, which confirms previous conclusions referring to online content (Ye et al., 2004; Weitjers et al., 2014; Punj, 2015), but is at odds with findings by, e.g., Yang et al. (2015) and Chyi and Lee (2013), though these did not refer particularly to online music or freemium services. Brands strive to move young consumers over to subscription-based services, but are failing to attract mass appeal (Spero and Stone, 2004). The advent of the internet and broadband penetration have allowed an easy access to online content for free through not only streaming services, but also peer-to-peer networks and illegal downloads, with the music industry being particularly affected by digital piracy. Historically, young, college age users are more likely to have positive attitudes towards music piracy and to practice it when compared to older individuals (Cesareo and Pastore, 2014; Weitjers et al. 2014). And though streaming and access-based music services are said to have contributed to reduce illegal downloads (Papies et al., 2011), with the migration from illegal to legal platforms becoming the norm (Sinclair and Green, 2016), a deeply entrenched 'free-lunch' mentality (Dou, 2004; Ye et al., 2004) remains and leads to the belief that 'content is free' (Li and Cheng, 2014; Pauwels and Weiss, 2008; Yang et al., 2015) and reference prices of zero (Punj, 2015), particular among the younger, savvy generations (Weitjers et al., 2014). Conversely, older users may have different reference prices, since these are formed based on previous experience (Papies et al., 2011) and, for these generations, content (and in particular music content) was not always available for free. Since reference prices are an important driver of willingness to pay, this may justify a higher purchase intention, given that people with a low 'free mentality' may believe that 'sacrifice' (i.e., paying a price) is necessary to receive appropriate services (Lin et al., 2013). Moreover, consumers with a low adaptation to advertisements may accept paid content because they feel more comfortable with online content without adds, while consumers that have experienced online advertisements for a long period may easily adapt to it (Li and Cheng, 2014). According to Weitjers et al. (2014), youngsters are more accustomed and thus more open to advertising than middle-aged adults, and hence older consumers seem to be less aversive to paying music platforms, not only because the 
for-fee version usually offers downloads, but also because it allows them to avoid adds. Furthermore, according to the same study, although quality is an important driver for the willingness to pay for music across all age groups, older consumers were the most represented among the 'quality seekers' segment. This may also contribute to a higher purchase intention of these consumers if they believe that the fee-based version is better than the free service. Finally, the higher level of income held by older customers may also contribute to a higher purchase intention, since youngsters' preference for free music is mainly driven by economic factors (Weitjers et al., (2014). In order to increase youngsters' purchase intention, MSS are advised to emotionally engage them. For young people, the symbolic meaning of consumption is particularly important (Lee and Yang, 2013). According to Spero and Stone (2004, p.154), a brand will not succeed unless young people connect with it emotionally and only an 'emotional difference can potentially command a premium'. If young users associated a symbolic and affective value towards MSS, value added services would be more important to them, as concluded by Kumar and Lim (2008). Though applied to a different context (mobile services), these authors suggest that youngsters are 'mobile lovers' (i.e., emotionally attached consumers) and that, as such, will likely pay additional charges for value added mobile services, since they appreciate them more for emotional benefits and social communication than for an instrumental purpose.

\section{Theoretical implications}

This study makes several contributions to the literature. Typically, previous studies about online music consumption mainly dealt with music piracy, file-sharing and illegal downloading, while there is a dearth of empirical research devoted to the willingness to pay for freemium access-based online music services. Furthermore, previous research on (mostly illegal) online music consumption mainly adopted two alternative approaches (Lin et al., 2013; Weitjers et al., 2014): researchers either studied usage intention and adoption, or willingness to pay for music. This is one of the few studies combining the two perspectives in order to examine users' intention towards paying for legal online music services (namely MSS) and, in particular, when a readable, free (though restricted) membership is available. Based on the TAM and on the VAM, we therefore contribute to the literature by empirically analysing what drives (or deters) users' intention to purchase MSS. In particular, since our study was based on a sample of streaming users, using the free-tier of the service, we were able to examine what drives their intention to switch from 'free to fee'. Furthermore, to the best of our knowledge, no prior study has segmented freemium MSS users in terms of their purchase intention. By analysing different segments of freemium MSS users according to age and gender, we show how these differ in their willingness to pay for the for-fee version of the service, contributing to shed some light on what may predict consumer purchasing behaviour towards MSS when free alternatives are available. 


\section{Practical implications}

Beyond theoretical contributions, the study also suggests several implications to MSS providers. The challenge of MSS to attract paying subscribers is increasingly difficult: P2P first and on-demand free music later (including the illegal sector and video streaming) facilitated the access to music, which is not a scarce content anymore. In order to mitigate the sense of technicality, a significant deterrent identified in this study, MSS should provide an easier and flawless experience, through, e.g., an interactive and user-friendly interface. Moreover, given that PV is mainly driven by PU when compared with PE, MSS providers are advised to invest in differentiating features, like, e.g., the quick access to music or the breadth of libraries available, since these seem to play a more important role than the joy to interact with the system itself. The study also suggests that the PF involved can prevent users from becoming actual subscribers, even when they find the service valuable. Therefore, and although authors such as Hamari et al. (2017a) and Papies et al. (2011) suggest that improving service quality, product features or catalogue size is unlikely to change this scenario, MSS providers need to consider how to generate revenue through balancing free and premium components, namely adjusting different strategies to different market segments (e.g., according to age and gender as discussed next), since there will always be consumers willing to pay, as long as they are targeted correctly (Wang et al., 2005).

Moreover, results show a significant contrast regarding consumers' willingness to pay for MSS in terms of gender and age, suggesting that providers should implement segmented strategies. Accordingly, in order to increase women's higher purchase proneness, MSS could develop the social capital of their platforms (namely, their premium version), by, e.g., emphasising group solidarity and the enjoyment of interacting with others, as well as the social networking and profile display features available (Sinclair and Green, 2016). Conversely, youngsters were proven to be less willing to pay for MSS. Given that music contributes to self-identity (Sinclair and Tinson, 2017) and the symbolic consumption of music is particularly salient for youth, especially aged between 18 and 24 (Larsen et al., 2010), MSS providers should move beyond functionality of the core service (currently, the main source of PV according to this study), emphasising and adding other features to the premium version, associated to the social aspects of music consumption, in order to engage young people emotionally and thus impact their willingness to pay. Added-value features such as allowing for creating a blog or building an online social network with like-minded others are likely to meet more emotional/passionate needs (Lin et al., 2013).

\section{Limitations and suggestions for future research}

Our study is not without limitations. Data were collected using a convenience sample, which warrants caution in generalising results. While youngsters are the highest-user segment of MSS (IFPI, 2017) and thus match the population of interest as acknowledged by previous studies (e.g., Chen et al., 2018b), the findings of this study should be further validated, namely including a larger proportion of older consumers in order to provide a more comprehensive view. Future research is also recommended to examine differences between other generations, between different ethnic groups, and other socio-demographic variables, as well as to perform a multi-group comparison to assess whether specific path 
coefficients in the model differ significantly among them. A comparative analysis of different platforms offering MSSs, namely audio (e.g., Spotify) versus video (e.g., YouTube) streaming platforms, would be particularly relevant, since according to the IFPI (2018) video streaming already makes up more than half of on-demand streaming time. Moreover, only freemium MSS users adopting the free-tier of the service were surveyed in this study, which might have introduced some bias in the results. Future studies could be less selective while defining the population of interest and could explore the differences between users and non-users of MSS, as well as between paying and non-paying users. Also, a mixed methods approach could not only capture richer data but also lead to a stronger contribution. Furthermore, and considering the relatively low explained variance in MSS purchase intention, other predictors could have been considered, such as prior usage, the duration of membership, individual level of tolerance to advertising, preference for digital devices, general interest in music, users' income and free mentality/price sensitivity. Since the kind of value perceived by streaming users was not specified in the questionnaire (e.g., quality, convenience; social capital), future studies could analyse what attributes do streaming users value the most and if this changes according to age or gender. Moreover, and as suggested by Weitjers et al. (2014), another recommendation for future research could be to study not only the direct cost of music (namely, PF), but also the psychological cost associated to the exposure to advertising. Another avenue for future research could be to incorporate the impact of perceived critical mass (i.e., the degree to which a person believes that most of his or her peers are using the system) on the usability aspect of MSS considered in the model, as suggested by Chen et al. (2018a). Finally, though the study is developed in a specific context (MSS), we believe these findings can be adapted to other online content services based on the freemium revenue model and provide a 'starting point' that future research should extend and further refine.

\section{References}

Anderl, E., März, A. and Schumann, J. (2016) 'Nonmonetary customer value contributions in free e-services', Journal of Strategic Marketing, Vol. 24, Nos. 3-4, pp.175-189.

Anderson, C. (2009) Free - The Future of a Radical Price, Random House, London.

Anderson, J. and Gerbing, D. (1988) 'Structural equation modeling in practice - a review and recommended two-step approach', Psychology Bulletin, Vol. 103, No. 3, pp.411-423.

Andersson, P. and Heinonen, K. (2002) Acceptance of Mobile Services: Insights from the Swedish Market for Mobile Telephony, p.16, SSE/EFI Working Paper Series on Business Administration 2002.

Bagozzi, R. and Yi, Y. (1988) 'On the evaluation of structural equation models', Journal of the Academy of Marketing Science, Vol. 16, No. 1, pp.74-94.

Bardhi, F. and Eckhardt, G. (2012) 'Access-based consumption: the case of car sharing', Journal of Consumer Research, Vol. 39, No. 4, pp.881-898.

Borges, M., Rita, P. and Pagani, M. (2015) 'An exploratory study into the determinants of adoption of mobile TV services: an integrated value perspective', International Journal of Electronic Business, Vol. 12, No. 1, pp.70-94

Brown, M. Pope, N. and Voges, K. (2003) 'Buying or browsing? An exploration of shopping orientations and online purchase intention', European Journal of Marketing, Vol. 37, Nos. 11/12, pp.1666-1684. 
Cesareo, L. and Pastore, A. (2014) 'Consumers' attitude and behavior towards online music piracy and subscription-based services', Journal of Consumer Marketing, Vol. 31, Nos. 6-7, pp.515-525.

Chen, A., Lu, Y. and Wang, B. (2016) 'Enhancing perceived enjoyment in social games through social and gaming factors', Information, Technology \& People, Vol. 9, No. 1, pp.99-119.

Chen, C., Leon, S. and Nakayama, M. (2018a) 'Converting music streaming free users to paid subscribers: social influence or hedonic performance', International Journal of Electronic Business, Vol. 14, No. 2, pp.128-145.

Chen, C., Leon, S. and Nakayama, M. (2018b) 'Are you hooked on paid music streaming? An investigation into the millennial generation', International Journal of E-Business Research, Vol. 14, No. 1, pp.1-20.

Cheong, J. and Park, M. (2005) 'Mobile internet acceptance in Korea', Internet Research, Vol. 15, No. 2, pp.125-140.

Chiu, Y., Lin, C. and Tang, L. (2005) 'Gender differences: assessing a model of online purchase intentions in e-tail service', International Journal of Service Industry Management, Vol. 16, No. 5, pp.416-435.

Chu, C-W. and Lu, H-P. (2007) 'Factors influencing online music purchase intention in Taiwan: an empirical study based on the value intention framework', Internet Research, Vol. 17, No. 2, pp.139-155.

Chyi, H. and Lee, H. (2013) 'Online news consumption: a structural model linking preference, use, and paying intent', Digital Journalism, Vol. 1, No. 2, pp.194-211.

Cyr, D. and Bonanni, C. (2005) 'Gender and website design in e-business', International Journal of Electronic Business, Vol. 3, No. 6, pp.565-582.

Davis, F. (1989) 'Perceived usefulness, perceived ease of use, and user acceptance of information technology', MIS Quarterly, Vol. 13, No. 3, pp.318-339.

Davis, F. (1993) 'User acceptance of information technology: system characteristics, user perceptions and behavioral impacts', International Journal of Man-Machine Studies, Vol. 38 , No. 3, pp.475-487.

Diamantopoulos, A. and Winklhofer, H. (2001) 'Index construction with formative indicators: an alternative to scale development', Journal of Marketing Research, Vol. 38, No. 2, pp.269-277.

Dinsmore, J., Swani, K. and Dugan, R. (2017) 'To 'free' or not to 'free': trait predictors of mobile app purchasing tendencies', Psychology \& Marketing, Vol. 34, No. 2, pp.227-244.

Doerr, J., Benlian, A., Vetter, J. and Hess, T. (2010) 'Pricing of content services - an empirical investigation of music as a service', in Nelson et al. (Eds.): Sustainable e-Business Management, pp.13-24, Springer, Berlin, Heidelberg.

Donthu, N. and Garcia, A. (1999) 'The internet shopper', Journal of Advertising Research, Vol. 39, No. 3, pp.52-52.

Dorr, J., Wagner, T., Benlian, A. and Hess, T. (2013) 'Music as a service: an alternative to music piracy? An empirical investigation of the intention to use music streaming services', Business \& Information Systems Engineering, Vol. 5, No. 6, pp.383-396.

Dou, W. (2004) 'Will internet users pay for online content?', Journal of Advertising Research, Vol. 44, No. 4, pp.349-359

Fornell, C. and Larcker, D. (1981) 'Structural equation models with unobservable variables and measurement error', Journal of Marketing Research, Vol. 18, No. 3, pp.382-388.

Hair, J., Black, W., Babin, B. and Anderson, R. (2010) Multivariate Data Analysis, Prentice Hall, Upper Saddle River, NJ.

Hair, J., Ringle, C. and Sarstedt, M. (2011) 'PLS-SEM: indeed a silver bullet', Journal of Marketing Theory and Practice, Vol. 19, No. 2, pp.139-152.

Hair, J., Sarstedt, M., Ringle, C. and Mena, J. (2012) 'An assessment of the use of partial least squares structural equation modeling in marketing research', Journal of the Academy of Marketing Science, Vol. 40, No. 3, pp.414-433. 
Hamari, J., Alha, K., Jarvela, S., Kivikangas, J., Koivisto, J. and Paavilainen, J. (2017b) 'Why do players buy in-game content? An empirical study on concrete purchase motivations', Computers in Human Behavior, March, Vol. 68, pp.538-546.

Hamari, J., Hannerb, N. and Koivistoa, J. (2017a) 'Service quality explains why people use freemium services but not if they go premium: An empirical study in free-to-play games', International Journal of Information Management, Vol. 37, No. 1, pp.1449-1459.

Hamari, J., Sjoklint, M. and Ukkonen, A. (2016) 'The sharing economy: why people participate in collaborative consumption', Journal of the Association for Information Science and Technology, Vol. 67, No. 9, pp.2047-2059.

Hampton-Sosa, W. (2017) 'The impact of creativity and community facilitation on music streaming adoption and digital piracy', Computers in Human Behavior, April, Vol. 69, pp.444-453.

Harman, H. (1976) Modern Factor Analysis, University of Chicago Press, Chicago.

Henseler, J., Ringle, C. and Sinkovics, R. (2009) 'The use of partial least squares path modeling in international marketing', New Challenges to International Marketing, pp.277-319, Emerald Group Publishing Limited.

Hollebeek, L, Malthouse, E. and Block, M. (2016) 'Sounds of music: exploring consumers' musical engagement', Journal of Consumer Marketing, Vol. 33, No. 6, pp.417-427.

Hsiao, K. and Chen, C. (2016) 'What drives in-app purchase intention for mobile games? An examination of perceived values and loyalty', Electronic Commerce Research and Applications, March-April, Vol. 16, pp.18-29.

Hwang, Y. (2010) 'The moderating effects of gender on e-commerce systems adoption factors: an empirical investigation', Computers in Human Behavior, Vol. 20, No. 6, p.20.

IFPI (2016) 'Music consumption exploding worldwide', Global Music Report [online] http://www.ifpi.org/news/IFPI-GLOBAL-MUSIC-REPORT-2016.pdf (accessed 22 April 2018).

IFPI (2017) 'Connecting with music', Music Consumer Insight Report [online] http://www.ifpi.org/ news/IFPI-releases-2017-music-consumer-insight-report-2017.pdf (accessed 22 April 2018).

IFPI (2018) 'Music is an integral part of our lives', Music Consumer Insight Report [online] https://www.ifpi.org/downloads/Music-Consumer-Insight-Report-2018.pdf (accessed 27 December 2018).

Kim, H-W., Chan, H. and Gupta, S. (2007) 'Value-based adoption of mobile internet: an empirical investigation', Decision Support Systems, Vol. 43, No. 1, pp.111-126.

Kumar, A. and Lim, H. (2008) 'Age differences in mobile service perceptions: comparison of Generation Y and baby boomers', Journal of Services Marketing, Vol. 22, No. 7, pp.568-577.

Kumar, A. and Lim, H. (2008) 'Age differences in mobile service perceptions: comparison of Generation Y and baby boomers', Journal of Services Marketing, Vol. 22, No. 7, pp.568-577.

Larsen, G., Lawson, R. and Todd, S. (2010) 'The symbolic consumption of music', Journal of Marketing Management, Vol. 26, Nos. 7/8, pp.671-685.

Lee, H. and Yang, K. (2013) 'Interpersonal service quality, self-service technology (SST) service quality, and retail patronage', Journal of Retailing and Consumer Services, Vol. 20, No. 1, pp.51-57.

Leon, S. (2018) 'Service mobile apps: a millennial generation perspective', Industrial Management \& Data Systems, Vol. 118, No. 9, pp.1837-1860.

Li, Z. and Cheng, Y. (2014) 'From free to fee: exploring the antecedents of consumer intention to switch to paid online content', Journal of Electronic Commerce Research, Vol. 15, No. 4, pp.281-299.

Liao, Z. and Cheung, M. (2001) 'Internet-based e-shopping and consumer attitudes: an empirical study', Information Management, Vol. 38, No. 5, pp.299-306.

Liébana-Cabanillas, F., Muñoz-Leiva, F. and Sánchez-Fernández, J. (2018) 'A global approach to the analysis of user behavior in mobile paying systems in the new electronic environment', Service Business, Vol. 12, No. 1, pp.25-64. 
Liébana-Cabanillas, F., Sánchez-Fernández, J. and Muñoz-Leiva, F. (2014) 'Antecedents of the adoption of the new mobile payment systems: the moderating effect of age', Computers in Human Behavior, June, Vol. 35, pp.464-478.

Lin, T., Hsu, J. and Chen, H. (2013) 'Customer willingness to pay for online music: the role of free mentality’, Journal of Electronic Commerce Research, Vol. 14, No. 4, pp.315-333.

Lu, H-P. and Hsiao, K-L. (2010) 'The influence of extro/introversion on the intention to pay for social networking sites', Information Management, Vol. 47, No. 3, pp.150-157.

Manis, K. and Choi, D. (2018) 'The virtual reality hardware acceptance model (VR-HAM): extending and individuating the technology acceptance model (TAM) for virtual reality hardware', Journal of Business Research, DOI: 10.1016/j.jbusres.2018.10.021.

Mantymaki, M. and Salo, J. (2015) 'Why do teens spend real money in virtual worlds? A consumption values and development psychology perspective on virtual consumption', International Journal of Information Management, Vol. 35, No. 1, pp.124-134.

Moon, J. and Kim, Y. (2001) 'Extending the TAM for World-Wide-Web context', Information Management, Vol. 38, No. 4, pp.217-230.

Morgan-Thomas, A. and Veloutsou, C. (2013) 'Beyond technology acceptance: Brand relationships and online brand experience', Journal of Business Research, Vol. 66, No. 1, pp.21-27.

Morris, M. and Venkatesh, V. (2000) 'Age differences in technology adoption decisions: implications for a changing work force', Personnel Psychology, Vol. 53, No. 2, pp.375-403.

Nunnaly, J. (1978) Psychometric Theory, McGraw-Hill, New York.

Nylén, D. and Holmström, J. (2015) 'Digital innovation strategy: a framework for diagnosing and improving digital product and service innovation', Business Horizons, Vol. 58, No. 1, pp.57-67.

Nysveen, H., Pedersen, P. and Thorbjørnsen, H. (2005) 'Intentions to use mobile services: antecedents and cross-service comparisons', Journal of the Academy of Marketing Science, Vol. 33, No. 3, pp.330-346.

Oestreicher-Singer, G. and Zalmanson, L. (2013) 'Content or community? A digital business strategy for content providers in the social age', MIS Quarterly, Vol. 37, No. 2, pp.591-616.

Pagani, M. (2004) 'Determinants of adoption of third generation mobile multimedia services', Journal of Interactive Marketing, Vol. 18, No. 3, pp.46-59.

Papies, D., Eggers, F. and Wlömert, N. (2011) 'Music for free? How free ad-funded downloads affect consumer choice', Journal of the Academy of Marketing Science, Vol. 39, No. 5, pp.777-794.

Pauwels, K. and Weiss, A. (2008) 'Moving from free to fee: how online firms market to change their business model successfully', Journal of Marketing, Vol. 72, No. 3, pp.14-31.

Pavlou, P., Liang, H. and Xue, Y. (2007) 'Understanding and mitigating uncertainty in online exchange relationships: a principal-agent perspective', MIS Quarterly, Vol. 31, No. 1, pp.105-136.

Podsakoff, P., MacKenzie, S. and Podsakoff, N. (2012) 'Sources of method bias in social science research and recommendations on how to control it', Annual Review of Psychology, Vol. 65, No. 1, pp.539-569.

Podsakoff, P., MacKenzie, S., Lee, J. and Podsakoff, N. (2003) 'Common method biases in behavioral research: a critical review of the literature and recommended remedies', Journal of Applied Psychology, Vol. 88, No. 5, pp.879-903.

Prensky, M. (2001) 'Digital natives, digital immigrants part I', On the Horizon, Vol. 9, No. 5, pp.1-6.

Punj, G. (2015) 'The relationship between consumer characteristics and willingness to pay for general online content: implications for content providers considering subscription-based business models', Marketing Letters, Vol. 26, No. 2, pp.175-186. 
PwC (2015) Consumer Intelligence Series: The Sharing Economy [online] http://www.pwc.com/us/ en/industry/entertainment-media/publications/consumer-intelligence-series/assets/pwc-cissharing-economy.pdf (accessed 22 April 2018).

Reinartz, W., Haenlein, M. and Henseler, J. (2009) 'An empirical comparison of the efficacy of covariance-based and variance-based SEM', International Journal of Research in Marketing, September, Vol. 26, No. 4, pp.332-344.

Shin, J., Park, Y. and Lee, D. (2018) 'Who will be smart home users? An analysis of adoption and diffusion of smart homes', Technological Forecasting and Social Change, September, Vol. 134, pp.246-253.

Sinclair, G. and Green, T. (2016) 'Download or stream? Steal or buy? Developing a typology of today's music consumer', Journal of Consumer Behavior, Vol. 15, No. 1, pp.3-14.

Sinclair, G. and Tinson, J. (2017) 'Psychological ownership and music streaming consumption', Journal of Business Research, February, Vol. 71, pp.1-9.

Slyke, C., Comunale, C. and Belanger, F. (2002) 'Gender differences in perceptions of web-based shopping', Communications of the ACM, Vol. 45, No. 7, pp.82-86.

Sorce, P., Perotti, V. and Widrick, S. (2005) 'Attitude and age differences in online buying', International Journal of Retail \& Distribution Management, Vol. 33, No. 2, pp.122-132.

Spero, I. and Stone, M. (2004) 'Agents of change: how young consumers are changing the world of marketing, Qualitative Market Research: An International Journal, Vol. 7, No. 2, pp.153-159.

Stafford, T., Stafford, M. and Schkade, L. (2004) 'Determining uses and gratifications for the internet', Decision Sciences, Vol. 35, No. 2, pp.259-285.

Statista (2017) Number of Music Streaming Subscribers Worldwide from 2010 to 2020 [online] https://www.statista.com/statistics/669113/number-music-streaming-subscribers/ (accessed 22 April 2018).

Statista (2018a) Number of Spotify's and Pandora's Active Users from 2017 to 2022 (in Millions) [online] https://www.statista.com/statistics/293749/spotify-pandora-number-active-users/ (accessed 27 December 2018).

Statista (2018b) Music Streaming Worldwide [online] https://www.statista.com/outlook/209/100/ music-streaming/worldwide (accessed 27 December 2018).

Teo, T. and Lim, V. (1996) 'Factors influencing personal computer usage: the gender gap', Women in Management Review, Vol. 11, No. 8, pp.18-26.

Teo, T., Lim, V. and Lai, R. (1999) 'Intrinsic and extrinsic motivation in internet usage', Omega: International Journal of Management Science, Vol. 27, No. 1, pp.25-37.

Van der Heijden, H. (2004) 'User acceptance of hedonic information systems', MIS Quarterly, Vol. 28, No. 4, pp.695-704.

Veit, D., Clemons, E., Benlian, A, Buxmann, P., Hess, T., Kundisch, D., Leimeister, J., Loos, P. and Spann, M. (2014) 'Business models', Business \& Information Systems Engineering, Vol. 6, No. 1, pp.45-53.

Venkatesh, V. and Bala, H. (2008) 'Technology acceptance model 3 and a research agenda on interventions', Decision Sciences, Vol. 39, No. 2, pp.273-315.

Venkatesh, V. and Morris, M. (2000) 'Why don't men ever stop to ask for directions? Gender, social influence, and their role in technology acceptance and usage behaviour', MIS Quarterly, Vol. 24, No. 1, pp.115-139.

Venkatesh, V. and Morris, M. (2008) 'Why don't men ever stop to ask for directions? Gender, social influence, and their role in technology acceptance and usage behavior', MIS Quarterly, Vol. 24, No. 1, pp.115-139.

Vock, M., Van Dolen, W. and De Ruyter, K. (2013) 'Understanding willingness to pay for social network sites', Journal of Service Research, Vol. 16, No. 3, pp.311-325. 
Wagner, T., Benlian, A. and Hess, T. (2014) 'Converting freemium customers from free to premium - the role of the perceived premium fit in the case of music as a service', Electronic Markets, Vol. 24, No. 4, pp.259-268.

Wang, C., Ye, L., Zhang, Y. and Nguyen, D. (2005) 'Subscription to fee-based online services: what makes consumer pay for online content', Journal of Electronic Commerce Research, Vol. 6, No. 4, pp.304-311.

Wang, Y-S. (2008) 'Assessing e-commerce systems success: a re-specification and validation of the DeLone and McLean model of IS success', Information Systems Journal, Vol. 18, No. 5, pp.529-557.

Wang, Y-S., Yeh, C-H. and Liao, Y-W. (2013) 'What drives purchase intention in the context of online content services? The moderating role of ethical self-efficacy for online piracy', International Journal of Information Management, Vol. 33, No. 1, pp.199-208.

Wang, Y-Y., Lin, H-H., Wang, Y-S., Shih, Y-H. and Wang, S-T. (2018) 'What drives users' intentions to purchase a GPS Navigation app: the moderating role of perceived availability of free substitutes', Internet Research, Vol. 28, No. 1, pp.251-274.

Warr, R. and Goode, M. (2011) 'Is the music industry stuck between a rock and a hard place? The role of the internet and three possible scenarios', Journal of Retailing and Consumer Services, Vol. 18, No. 2, pp.126-131.

Weitjers, B., Goedertier, F. and Verstreken, S. (2014) 'Online music consumption in today's technological context: putting the influence of ethics in perspective', Journal of Business Ethics, Vol. 124, No. 4, pp.537-550.

Wlömert, N. and Papies, D. (2016) 'On-demand streaming services and music industry revenues insights from Spotify's market entry', International Journal of Research in Marketing, Vol. 33, No. 2, pp.314-327.

$\mathrm{Wu}$, L.H., Wu, L.C. and Chang, S.C. (2016) 'Exploring consumers' intention to accept smartwatch', Computers in Human Behavior, November, Vol. 64, pp.383-392.

Yang, L., Ha, L., Wang, F. and Abuljadail, M. (2015) 'Who pays for online content? A media dependency perspective comparing young and older people', International Journal on Media Management, Vol. 17, No. 4, pp.277-294.

Ye, L., Zhang, Y., Nguyen, D. and Chiu, J. (2004) 'Fee-based online services: exploring consumers' willingness to pay', Journal of International Technology and Information Management, Vol. 13, No. 1, pp.133-141.

Zhang, T., Lu, C. and Kizildag, M. (2018) 'Banking 'on-the-go': examining consumers' adoption of mobile banking services', International Journal of Quality and Service Sciences, Vol. 10, No. 3, pp.279-295.

Zheng, X., Cheung, C., Lee, M. and Liang, L. (2015) 'Building brand loyalty through user engagement in online brand communities in social networking sites', Information, Technology \& People, Vol. 28, No. 1, pp.90-106. 